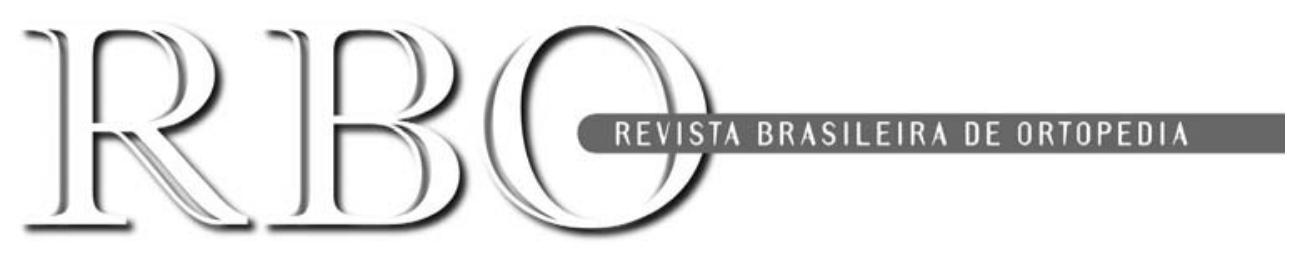

\title{
Editorial
}

\section{Ensino da Ortopedia nas Escolas Médicas do Brasil}

A preocupação com o ensino da graduação médica tem sido tema de vários debates no meio acadêmico pelo relativo descaso por parte das disciplinas da área clínica que favorecem a formação do residente com ênfase nas especialidades médicas.

Não é fácil, do ponto de vista pedagógico, focar exatamente o que o aluno deve aprender dentro de cada área.

Não existe um esmero por parte dos docentes em preparar uma aula voltada aos objetivos para um médico generalista. Em geral, as aulas ministradas na graduação são as mesmas dos residentes com óbvio desinteresse por parte do alunado. Essas aulas, ou mesmo as discussões de casos clínicos, aprofundam-se em temas que visam a formação do especialista e não do aluno.

$\mathrm{Na}$ Ortopedia e Traumatologia estes aspectos fazem-se notar de um modo muito mais evidente, em que quase tudo está voltado para a pós-graduação lato sensu tanto na educação continuada como na formação dos residentes.

A excelência conseguida na formação do ortopedista fica evidenciada pela excelência do exame final de avaliação considerado como referência dentre todas as especialidades médicas.

Todavia, este fato aprofunda ainda mais o abismo existente entre a pós-graduação lato sensu e a graduação médica em Ortopedia que, salvo raras exceções, praticamente inexiste atualmente no Brasil.

Em uma avaliação que fizemos recentemente, mais da metade das 178 escolas médicas brasileiras mostram em sua grade de ensino uma pífia presença da ortopedia, inserida apenas dentro da cirurgia como discussão de casos tipo PBL. Destarte a precariedade do ensino médico que assola o Brasil inversamente proporcional ao número crescente de novas escolas, este fato deve ser revertido.

É como se a Ortopedia e Traumatologia fosse considerada uma especialidade apenas de pósgraduação, não necessária para a formação do médico.

Entretanto, se formos nos basear no ponto de vista epidemiológico para elaborarmos um currículo consentâneo com a realidade nacional, sabe-se que $60 \%$ das admissões de pronto-atendimento são pacientes com traumatismo musculoesquelético. É consenso, baseado nesses dados estatísticos, que o graduando deve ter condições de exercer uma atuação de nível secundário em ortopedia com ênfase para o politraumatizado mesmo que não pretenda exercer esta especialidade. 
É inadmissível que o interno faça uma reanimação de um paciente com parada cardíaca, controle um paciente em coma diabético, mas não tenha formação cognitiva diante de um paciente com uma fratura exposta, já que estas situações ocorrem com igual frequência num pronto-atendimento.

Sabemos, entretanto, que muitas escolas médicas carecem de um pronto-atendimento com volume diário de pacientes politraumatizados que possibilite um bom treinamento prático do aluno.

Isto sem citar os pacientes ambulatoriais para o diagnóstico precoce de afecções ortopédicas que são fundamentais para um melhor prognóstico como nas deformidades congênitas e do desenvolvimento do sistema musculoesquelético.

O curso de Ortopedia na graduação, quando existente, tem um caráter apenas informativo e não formativo, em que as várias doenças são mostradas superficialmente sem que o aluno tenha um envolvimento ou responsabilidade sobre o paciente mesmo no internato. A formação cognitiva e de habilidades específicas para que este que atue na prática fica restrito atualmente ao residente de ortopedia.

Não será tarefa fácil revertermos este quadro desalentador. Esbarramos em modificações estruturais do currículo médico dentro das comissões de graduação, da congregação, dos docentes e até mesmo no MEC.

Infelizmente, um professor de ortopedia não tem presença ativa nesses colegiados, já que se preocupa muito mais com a formação do residente e não do aluno.

Algumas escolas nem mesmo possuem um professor titular de ortopedia para que este possa participar e influenciar nestas mudanças. Poucos são os titulares de ortopedia concursados em livredocência e que possuem assim um cabedal pedagógico e didático para modificar esta situação dentro de uma congregação universitária.

Devemos alertar os poucos Professores Titulares de Ortopedia existentes no Brasil, para que constituam uma nova geração de mestres e doutores, que estejam voltados realmente ao ensino da graduação e que tenham projetos de pesquisa onde sejam incluídos alunos de Iniciação Científica.

O mote para a reestruturação dos cursos de Ortopedia está justamente em motivar o aluno precocemente envolvendo-o em trabalhos clínicos, epidemiológicos e experimentais, fazendo com que tenha uma base sólida baseada na participação deste em publicações originais que irão alavancar o ensino e, progressivamente, aumentar o nosso espaço dentro do currículo nuclear da graduação.

A criação de disciplinas optativas também tem importante papel neste contexto, já que irá atrair o alunado para uma nova área de atuação. A amplitude de opções dentro da nossa especialidade permite que possamos motivá-los para áreas novas, tais como: Traumatologia Esportiva, Microcirurgia Reconstrutiva, Geriatria Ortopédica e outras.

A elaboração de um programa único nacional para o ensino da Ortopedia e Traumatologia, o lançamento de um livro didaticamente voltado para o aluno, a instalação de um portal exclusivo para a graduação no site da SBOT e o monitoramento permanente de todas as escolas médicas para verificar como está o ensino da nossa especialidade são medidas que devem ser tomadas em caráter de urgência.

O ensino bem estruturado da Ortopedia na graduação é a base fundamental para que possamos sedimentar na academia e, por conseguinte, na sociedade, a nossa especialidade, como uma das mais participativas no objetivo final comum que é melhorar a saúde em nosso país. 